\title{
INKORPORASI SULFUR DALAM PROTEIN ONGGOK MELALUI TEKNOLOGI FERMENTASI MENGGUNAKAN SACCHAROMYCES CEREVISIAE
}

\section{INCORPORATION OF SULFUR IN CASSAVA WASTE PROTEINS BY USING TECHNOLOGY FERMENTATION WITH SACCHAROMYCES CEREVISIAE}

\author{
Wara Pratitis Sabar Suprayogi \\ Jurusan Peternakan, Fakultas Pertanian, Universitas Sebelas Maret
}

\begin{abstract}
ABSTRAK
Penelitian ini bertujuan untuk mengetahui pengaruh lama inkubasi dan dosis sulfur dalam onggok fermentasi dengan Saccharomyces cerevisiae. Penelitian dilakukan secara invitro di Laboratorium Nutrisi dan Makanan Ternak, Jurusan Perternakan, Universitas Sebelas Maret surakarta.Pelaksanaan penelitian dilakukan selama 3 bulan.

Materi penelitian adalah onggok yang difermentasi dengan kapang Saccharomyces cerevisiae dengan perlakuan dosis sulfur yaitu 0 dan $1500 \mathrm{mg} / \mathrm{kg}$ substrat (Kadar air 60\%), lama inkubasi 2, 3 dan 4 hari. Hasil penelitian di analisis ragam dengan menggunakan Rancangan Acak Lengkap Pola Faktorial 2x3 dan setiap perlakuan diulang 3 kali.

Hasil analisis variansi menunjukkan bahwa onggok yang difermentasi dengan Saccharomyces cerevisiae dengan lama inkubasi 3 hari dan penambahan sulfur $1500 \mathrm{mg} / \mathrm{kg}$ dapat meningkatkan bahan organik dan kandungan protein biomassa hasil fermentasi secara signifikan $(\mathrm{p}<0,05)$ namun kadar serat kasar menunjukkan pengaruh yang berbeda tidak nyata.
\end{abstract}

Kata kunci : onggok ,fermentasi, Saccharomyces cerevisiae, $\mathrm{NH}_{4} \mathrm{SO}_{4}$

\begin{abstract}
This research was conducted to determine the influence of incubation time and dose of sulphur in organik fermentation with Saccharomyces cerevisiae. This resech was in vitro at Laboratory Animal Nitrition. Departement Animal of Science, Agriculture Fakulty, Sebelas Maret University. This research was condukted for 3 month.

The material were used cassava fermented with fungi Saccharomyces cerevisiae. And and the treatment of dose sulphur at 0 and $1500 \mathrm{mg} / \mathrm{kg}$ of substrate (water content $60 \%$ ), time incubatin 2, 3 and 4 day. The result of experiment were analysed using completely randomozed design faktorial $2 \times 3$ and each treatment is repeated 3 time.

The results of variance analysis showed that cassava fermented with Saccharomyces cerevisia with 3 day incubation time and addition of sulfur $1500 \mathrm{mg} / \mathrm{kg}$ can increase organic matter and protein content of biomassa fermentation significantly $(p<0,05)$ but the level of crude fiber showed non significanly effects.
\end{abstract}

Keywords : Cassava, fermentation Saccharomyces cerevisiae, $\mathrm{NH}_{4} \mathrm{SO}_{4}$

\section{PENDAHULUAN}

Onggok atau ampas tapioka merupakan limbah pembuatan pati tapioka yang masih potensial digunakan sebagai pakan ruminansia, dimana kandungan nutrien onggok menurut Bo Gohl (1975) yaitu bahan kering 83,5\%, protein kasar 2,2\%, serat kasar 26,9\% dan bahan ektrak tanpa nitrogen (BETN) 66,9\%.

Onggok ini mudah rusak (busuk) karena kadar air bahan pakan ini cukup tinggi serta dapat mengakibatkan pencemaran lingkungan. Salah satu penanggulangannya dengan memanfaatkan bahan ini sebagai bahan pakan ternak. Onggok termasuk golongan pakan sumber energi dengan kandungan pati yang tinggi menjadikan bahan pakan ini mampu menyediakan energi tersedia bagi ternak. Untuk meningkatkan daya guna pakan ini, maka dengan teknologi fermentasi dapat memperbaiki nilai nutrisinya selain itu sekaligus dapat digunakan sebagai media sintesis mikrobia yang dapat memanfaatkan mineral in 
organik menjadi mineral organik. Pada akhirnya onggok selain sebagai sumber energi juga sebagai penyedia sulfur organik bagi pertumbuhan dan perkembangan mikrobia rumen.

Pertumbuhan kapang akan optimal apabila tersedia sumber nutrien yang dibutuhkan secara seimbang. Selain sumber C dan N untuk meningkatkan pertumbuhan kapang, kebutuhan minaral juga harus diperhatikan. Penyediaan mineral Sulfur cukup esennsial untuk pertumbuhan dan perkembangan kapang. Inkorporasi Sulfur (S) dalam protein onggok diupayakan untuk menyediakan unsur S organik sekaligus penyedia energi bagi kapang.

Onggok merupakan pakan yang cukup potensial sebagai sumber energi tersedia dan pengukusan yang dilakukan pada bahan pakan ini mampu meningkatkan nilai manfaat onggok (Manik, 1995). Upaya inkorporasi mineral anorganik menjadi mineral organik telah banyak dilakukan. Sebagaimana yang dikerjakan oleh Muktiani (2002), inkorporasi $\mathrm{Cr}$ dengan menggunakan substrat onggok untuk mengkaji bahwa untuk sintesis mikrobia rumen membutuhkan mineral Cr. Sedangkan (Manik, 1995) menjelaskan bahwa onggok yang dikukus ditambah urea lebih baik dibandingkan yang dikukus ditinjau dari peningkatan kecernaan nutrient (TDN), fermentasi oleh mikrobia rumen, penghematan penggunaan nitrogen/protein (protein sparing effect), glukoneogenesis dan retensi $\mathrm{N}$ nya. Perpaduan pengukusan onggok pada proses sterilisasi onggok pra-fermentasi dan inkorporasi Sulfur diharapkan dapat menopang kebutuhan Sulfur dan energi tersedia (available) bagi mikrobia rumen. Sehingga onggok dapat digunakan sebagai bahan pakan sumber energi dan mineral Sulfur organik serta kandungan protein yang cukup memadai.

Atas dasar pertimbangan di atas, maka penelitian ini dilakukan untuk mengkaji pengaruh dosis Sulfur dan lama inkubasi fermentasi onggok dengan menggunakan Saccharomyces cerevisiae,sehingga diharapkan onggok menjadi pakan ternak yang potensial dengan kualitas yang meningkat sebagai menyediakan energi dan mineral Sulfur organik bagi ternak, selain itu dapat mengurangi pencemaran lingkungan

\section{METODOLOGI PENELITIAN}

\section{Waktu dan Tempat Penelitian}

Penelitian dilaksanakan di Laboratorium

Ilmu Nutrisi dan Makanan Ternak, Jurusan Peternakan, Fakultas Pertanian UNS.

\section{Materi Penelitian}

Onggok sebagai media fermentasi, mineral sulfur dalan ammonium sulfat $\left(\mathrm{NH}_{4}\right)_{2} \mathrm{SO}_{4}$ dan kapang Saccharomyces cerevisiae.

\section{Metode Penelitian}

Percobaan ini dikerjakan dalam Rancangan Acak Lengkap pola faktorial $2 \times 3$. Faktor I dosis Sulfur $\left(\mathrm{NH}_{4}\right)_{2} \mathrm{SO}_{4}$ yaitu 0 dan $1500 \mathrm{mg} / \mathrm{kg}$. Faktor II lama inkubasi yaitu 2,3, dan 4 hari. Substrat yang digunakan untuk media tumbuh jamur Saccharomyces cerevisiae adalah onggok dengan proses sterilisasi dilakukan pengukusan selama 15 menit.Dosis jamur yang digunakan sebanyak $2 \%$ dari total onggok dengan kadar air $60 \%$. Inkubasi dilakukan mengikuti metode Muktiani (2002), percobaan ini dilakukan pada suhu ruang dengan diinkubasikan selama 2,3, dan 4 hari, serta dosis Sulfur yang disesuaikan dengan perlakuan. Perlakuan disusun dalam pola faktorial dengan menggunakan rancangan acak lengkap. Kombinasi perlakuan sebanyak 6, setiap perlakuan diulang 3 kali sehingga diperoleh 18 unit percobaan.

Peubah yang diamati adalah kandungan nutrien onggok fermentasi dengan metode analisis proksimat dan kadar $\mathrm{S}$ yang terinkorporasi ke dalam protein fungi, dengan menggunakan spektronik serapan atom (AAS). Pada tahap ini peubah yang diukur adalah kandungan Sulfur yang dianalisis dengan AAS dan kandungan protein kasar (PK) onggok dengan metode Kjeldahl (AOAC, 1980).

Penentuan kadar Air. Cara penentuan kadar air bahan yang terkandung dalam bahan pakan dapat diketahui dengan memanaskan bahan tersebut dalam oven pada suhu $105^{\circ} \mathrm{C}$ selama $8-24$ jam sehinga diperoleh berat konstan. Penentuan Kadar Protein kasar. Kadar protein kasar bahan pakan dapat dilakukan dengan metoda Kjeldhal dengan proses destruksi menggunakan asam sulfat pekat (H2SO4), destilasi menggunakan $\mathrm{NaOH}-\mathrm{Natiosulfat}$ dan dilanjutkan dengan titrasi dengan asam borak $4 \%$.

\section{Analisis Data}

Data yang diperoleh dianalisis dengan analisis ragam sesuai dengan rancangan acak lengkap (RAL) pola factorial 2 x 3 . Jika berbeda nyata dilakukan uji lanjut terhadap rataan dengan uji beda nyata DMRT (Astuti, 1980). 


\section{HASIL DAN PEMBAHASAN}

Hasil penelitian yang diperoleh meliputi kandungan protein kasar (PK), serat kasar(SK) dan bahan organik(BO) bahan pakan telah di analisis menggunakan metode proksimat.

\section{Kandungan Protein Kasar Onggok Fermentasi (\%)}

Protein merupakan salah satu komponen nutrien dalam bahan pakan. Kadar protein onggok yang terfermentasi dapat dilihat pada tabel 2.

Hasil analisis variansi menunjukkan bahwa onggok fermentasi dengan penambahan sulfur(B2) menghasilkan kandungan protein yang lebih tinggi dibanding dengan onggok fermentasi tanpa sulfur(B2) . Kenaikan protein kasar di sebabkan pertumbuhan kapang Saccharomyces cerevisiae lebih optimal pada penambahan sulfur, sedangkan mikrobia kapang merupakan sumber asam amino esensial.Pertumbuhan kapang sangat dipengaruhi oleh ketersedian sumber energi, sumber $\mathrm{N}$ dan beberapa mineral terutama $\mathrm{S}$ dan $\mathrm{P}$. Kultur mikrobia dalam fermentasi mampu menggunakan sumber mineral sulfur dari senyawa organik maupun anorganik seperti ammonium sulfat $\left(\mathrm{NH}_{4} \mathrm{SO}_{4}\right)$. Ferdiaz (1989) dalam Haryanto (1997) menyatakan bahwa melalui fermentasi selain meningkatkan kadar protein juga dapat meningkatkan kandungan vitamin bahan yang difermentasi terutama vitamin $\mathrm{B}_{12}$, riboflavin dan provitamin A.

Proses fermentasi dapat berjalan baik apabila dalam medium tersedia semua nutrien yang dibutuhkan mikrobia, serta kondisi fermentasi yang spesifik untuk masing-masing mikrobia (Rahman, 1989). Menurut Chuzaemi(1990) produksi mikroba dalam rumen dibatasi oleh ketersediaan energi, protein mudah larut dan mineral terutama S dan P.

\section{Kandungan Serat Kasar Onggok Fermentasi} (\%)

Serat kasar merupakan salah satu komponen penyusun karbohidrat diantaranya selulosa, hemiselulosa. kandungan serat kasar onggok fermentasi dapat dilihat pada tabel 3 .

Tabel 2. Kandungan Protein kasar onggok fermentasi(\%)

\begin{tabular}{|c|c|c|c|c|c|c|}
\hline & \multicolumn{2}{|c|}{ C1 (2 hari) } & \multicolumn{2}{|c|}{ C2 (3 hari) } & \multicolumn{2}{|l|}{ C3 } \\
\hline & B1 & B2 & B1 & B2 & B1 & B2 \\
\hline 1 & 3.31 & 2.96 & 2.66 & 2.9 & 2.13 & 2.89 \\
\hline 2 & 2.43 & 3.04 & 2.57 & 2.73 & 2.17 & 2.76 \\
\hline 3 & 2.79 & 2.39 & 2.32 & 2.97 & 2.52 & 2.76 \\
\hline Rataan & 2.84 & 2.8 & 2.52 & 2.87 & 2.27 & 2.80 \\
\hline Jumlah & 8.53 & 8.39 & 7.55 & 8.6 & 6.82 & 8.39 \\
\hline Rataan & \multicolumn{5}{|c|}{ Kadar Protein kasar(\%) } & \\
\hline B1 & \multicolumn{5}{|c|}{$2.54^{\mathrm{b}}$} & \\
\hline B2 & \multicolumn{5}{|c|}{$2.82^{\mathrm{a}}$} & \\
\hline
\end{tabular}

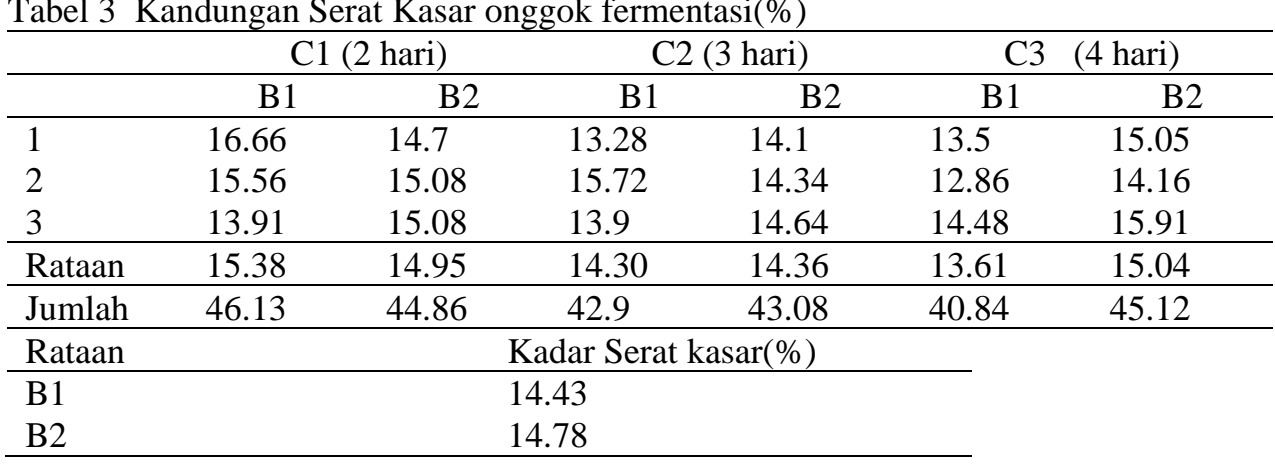


Tabel 4. Kandungan bahan organik onggok fermentasi

\begin{tabular}{|c|c|c|c|c|c|c|}
\hline & \multicolumn{2}{|c|}{ C1 (2 hari) } & \multicolumn{2}{|c|}{ C2 (3 hari) } & \multicolumn{2}{|c|}{ C3 } \\
\hline & B1 & B2 & B1 & B2 & B1 & B2 \\
\hline 1 & 96.89 & 96.17 & 98.82 & 98.96 & 97.89 & 95.49 \\
\hline 2 & 97.02 & 97.26 & 98.88 & 97.69 & 98.65 & 95.85 \\
\hline 3 & 98.29 & 95.69 & 98.07 & 97.79 & 96.9 & 95.05 \\
\hline Rataan & 97.40 & 96.37 & 98.59 & 98.15 & 98.27 & 95.46 \\
\hline Jumlah & 292.2 & 289.12 & 295.77 & 294.44 & 293.44 & 286.39 \\
\hline Rataan & \multicolumn{6}{|c|}{ Kadar Bahan organik(\%) } \\
\hline B1 & \multicolumn{6}{|c|}{$97.93^{\mathrm{a}}$} \\
\hline B2 & \multicolumn{6}{|c|}{$96.66^{\mathrm{b}}$} \\
\hline Rataan & \multicolumn{6}{|c|}{ Kadar Bahan organik(\%) } \\
\hline C1 & \multicolumn{6}{|c|}{$96.88^{\mathrm{b}}$} \\
\hline $\mathrm{C} 2$ & \multicolumn{6}{|c|}{$98.36^{\mathrm{a}}$} \\
\hline C3 & \multicolumn{6}{|c|}{$96.63^{b}$} \\
\hline
\end{tabular}

Hasil analisi variansi menunjukkan bahwa perlakuan lama peram dan penambahan mineral sulfur tidak memberikan pengaruh yang berbeda nyata. Hal ini menunjukkan hasil yang positif yang artinya onggok yang difermentasi dengan inokulum kapang Saccharomyces cerevisiae tidak menaikkan kadar serat kasar biomasa onggok, sedangkan inokulan kapang mempunyai kandungan serat kasar yang lebih tinggi dibandingkan dengan inokulan lain seperti bakteri maupun protozoa.

Senyawa karbohidrat komplek seperti pati, selulosa, pektin, lignoselulosa, dan serat umumnya dapat digunakan sebagai sumber $\mathrm{C}$ dan sumber energi medium fermentasi (Judoamidjojo et al,1992), dan secara biologis dapat diubah menjadi glukosa, maltosa,etanol, dektrin dan asam-asam organik yang bernilai ekonomis tinggi(Tisnadjaja, 1996).

\section{Kandungan Bahan Organik Onggok Fermentasi (\%)}

Bahan organik terdiri dari lemak kasar, protein kasar, serat kasar dan bahan ektrak tanpa nitrogen (BETN)(Tillman et al,1991). Hasil analisis kandungan bahan organik onggok fermentasi dapat dilihat pada tabel 4 .

Hasil analisis variansi menunjukkan bahwa kandungan bahan organik onggok fermentasi dengan sulfur (B2) dan tanpa sulfur(B1) serta lama peram 2 hari (C1), 3 hari (C2) dan 4 hari (C4) memberikan mengaruh yang signifikan. Hal ini berarti lama pertumbuhan dari kapang Saccharomyces cerevisiae untuk produksi yang optimal membutuhkan waktu inkubasi sekitar 3 hari setelah itu mengalami fase penurunan.secara organoleptis kenampakan pertumbuhan serabut seperti kapas pada hari ketiga lebih banyak dibanding hari ke dua dimana spora yang timbul akan berbentuk warna putih hal ini tergantung jenis kapang, dan kapang ini terdiri dari suatu thallus bercabang yang disebut hifa, dimana miselia merupakan massa hifa (Ferdiaz,1989). Sedangkan pengaruh penambahan Sulfur dalam proses fermentasi ternyata mampu menaikkan kandungan biomasa hasil fermentasi, selanjutnya keadaan ini terlihat adanya peningkatan bahan organik secara nyata $(\mathrm{p}<0,05)$. Menurut Chuzaemi(1994) produksi mikroba dibatasi oleh ketersediaan energi, protein mudah larut dan mineral terutama $\mathrm{S}$ dan $\mathrm{P}$.

\section{KESIMPULAN DAN SARAN}

\section{Kesimpulan}

Kesimpulan dari hasil penilitian ini adalah

1. Onggok yang difermentasi memerlukan tambahan unsur mineral sulfur untuk menghasilkan biomassa yang optimal

2. Lama inkubasi yang optimal untuk pertumbukan inokulan dibutuhkan waktu minimal 2 hari hal ini juga tergantung substrat yang digunakan sebagai media fermentasi

3. Kandungan protein kasar dan bahan organik biomassa hasil fermentasi meningkat pada lama inkubasi 3 harai dengan sulfur $\left(\mathrm{NH}_{4} \mathrm{SO}_{4}\right.$ ) $1500 \mathrm{mg} / \mathrm{kg}$ bahan kadar air $60 \%$

\section{Saran}

Teknologi fermentasi dengan menggunakan inokulan mikrobia hendaknya memperhatikan ketersedian nutrien untuk pertumbuhan mikrobia diantara sumber C, sumber $\mathrm{N}$ dan mineral yang tersedia dalam jumlah seimbang. 


\section{UCAPAN TERIMA KASIH}

Ucapan terima kasih disampaikan kepada DIPA BLU selaku pemberi dana pada penelitian ini hingga penyusunan laporan.

\section{DAFTAR PUSTAKA}

Astuti, M. 1980. Rancangan Percobaan dan Analisa Statistik. Bagian Pemuliaan Ternak. Fakultas Peternakan UGM.

Association of Official Analysis Chemist. 1980. Official methods of analysis of the Association of Official Analytical Chemist. 13th ed. Association of Official Analytical Chemist, Washington, DC.

Bo-Gohl. 1975. Tropical Feeds. Feed Information Summaries and Nutritive Value. United Version, FAO of The United nations. Rome. Hal. 95, 114-115.

Chuzaemi, S.,Bruchem J. V. 1990. Fisiologi nutrisi ruminansia. LUW - Unversitas Brawijaya. Animal Husbandry Project.

Fardiaz, S. 1989. disarikan dari Hardjo, S., Indrasti,N,S., Bantacut, T. Biokonversi : Pemanfaatan Limbah Industri Pertanian. Bahan Ajar. Departemen Pendidikan dan kebudayaan. Direktorat jendral Pendidikan Tinggi. Pusat Antar Universitas pangan dan Gizi Intitut Pertanian Bogor.
Haryanto, H. 1997. Pengaruh Lama Fermentasi Dengan Menggunakan Aspergillus niger Terhadap Kadar Asam Sianida, Protein Kasar dan Serat Kasar Inti Biji Karet. Skripsi. Fakultas Peternakan Universitas Jambi.

Judoamidjojo, R.M., E.G. Sa`id, L. Hartote. 1989. Biokonversi. Pusat Antar Universitas Bioteknologi., IPB.

Manik, I.G. 1985. Pengaruh Ubi Kayu dalam Campuran dengan Urea sebagai Ransum penguat terhadap Metabolisme Glukosa, Nitrogen dan Energi pada Kambing Menyusui dan Tidak Menyusui. Disertasi Bidang Keahlian Biologi, Fakultas Pasca Sarjana, IPB Bogor.

Muktiani, A. 2002. Penggunaan Hidrolisat Bulu Ayam dan Sorgum serta Suplemen Kromium Organik untuk Meningkatkan Produksi Susu pada sapi Perah. Disertasi. Program Pascasarjana. Institu

Tillman ,A.D., H. Hartadi, S. Reksohadiprodjo, s. Prawirokusumo dan S. Lebdosoekojo, 1991. Ilmu makanan Ternak Dasar. Gadjah Mada university press. Yogyakarta. 